\title{
An unusual case of paraspinal schwannoma causing undiagnosed low back pain
}

\section{Tanı konmamış bell ağ|rısına neden olan olağandışı bir paraspinal schwannom olgusu}

İsmaill Kaya

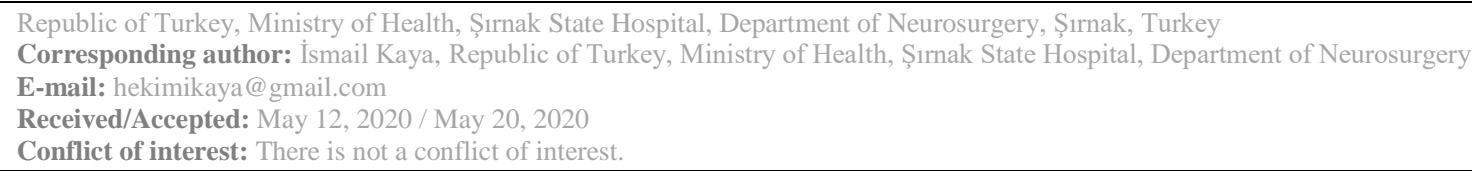

\section{SUMMARY}

Paraspinal schwannomas are relatively common but hardly classified subject of spinal neurosurgery. We present a rare and unclassified case of paravertebral schwannoma that causes non-discogenic low back pain. A 45year-old Caucasian female came to our clinic with low back pain. Her pain steadily worsened for two years. Her physical exam showed right straight leg raise positivity at 45-degree angle but provocation test negative. Magnetic resonance imaging showed a mass in the paravertebral muscle originating right lumbar 3-4 facet joint. According to planned surgery patient operated. Histopathological diagnosis confirmed as schwannoma. The patient followed for 2 years without pain and neurologic deficiency. Follow up magnetic resonance imaging showed no residue or recurrence of the mass. Schwannomas must be taken into account for differential diagnosis of unexplained non-discogenic low back pain. New classification systems must be offered based on widespread patient groups.

Keywords: Paraspinal schwannomas,non-discogenic low back pain,paraspinal schwannoma classification,surgical removal
İsmail Kaya

ORCID IDs of the authors:

İ.K. 0000-0002-4128-5845

\section{ÖZET}

Paraspinal schwannomlar göreceli olarak yaygın olmakla birlikte spinal cerrahide yeterli sınıflandırılamamıș bir konudur. Diskojenik olmayan bel ağrısına neden olan nadir ve sınıflandırılmamış paravertebral schwannom olgusunu sunuyoruz. 45 yaşında kadın hasta bel ağrısı ile kliniğimize geldi. Şikayeti iki yıl içinde mütemadiyen kötüleşti. Fizik muayenesinde, sağ bacakta 45 derecelik açıda laseque testinde pozitiflik vardı, ancak provokasyon testi negatif olduğu görüldü. Manyetik rezonans görüntülemede paravertebral kasta sağ lomber 3-4 faset eklem kaynaklı bir kitle saptandı. Planlanan cerrahiye göre hasta ameliyat edildi. Histopatolojik tanı schwannom olarak doğrulandı. Hasta 2 sene boyunca ağrı ve nörolojik defisit olmadan takip etti. Takip manyetik rezonans görüntülemesinde kitle kalıntısı veya nüksü izlenmedi. Açıklanamayan diskojenik olmayan bel ağrısının ayırıcı tanısı için Schwannomlar dikkate alınmalıdır. Yaygın hasta gruplarına göre yeni sinıflandırma sistemleri sunulmalıdır.

Anahtar sözcükkler: Paraspinal schwannoma,diskojenik olmayan bel ağrısı,paraspinal schwannom sınıflandırması, cerrahi rezeksiyon

\section{INTRODUCTION}

Paraspinal schwannomas are relatively common but hardly classified subject of spinal neurosurgery. Schwannomas are rare causes of non-discogenic low back pain. We present an unusual case of paravertebral schwannoma that causes non-discogenic low back pain. 


\section{CASE REPORT}

A 45-year-old Caucasian female came to our clinic with low back pain at her right flank. She didn't describe neurologic claudication. Her pain steadily worsened for two years. The patient applied to other hospitals in the area, but they couldn't find a reason. Her complaints have been worsened for 2 months and she has no incontinence.

Her physical exam showed right straight leg raise test positivity at 45 -degree angle but provocation test negative.

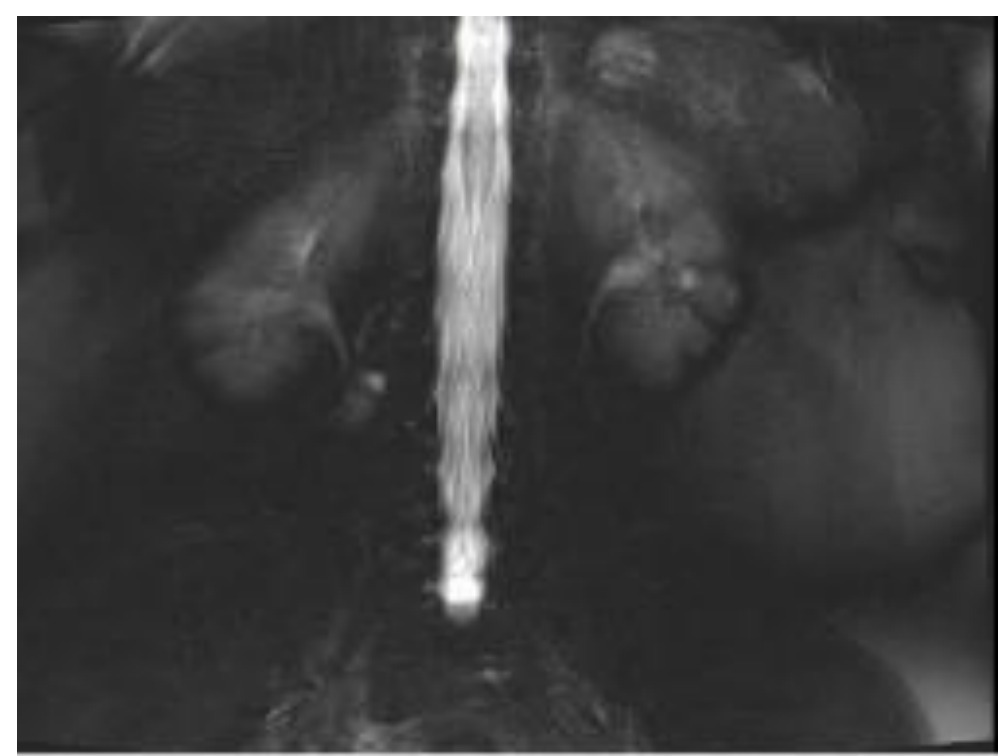

Figure 1: Magnetic resonance myelogram.

Magnetic resonance myelogram showed no cerebrospinal fluid flow obstruction (Figure 1). Careful evaluation of $\mathrm{T} 1$ weighted images showed a hypointense contrast-enhancing mass in the paravertebral muscle originating from the right lumbar (L) 3-4 facet joint (Figure 2). T2 weighted images showed a hyperintense mass in the same region (Figure 3).

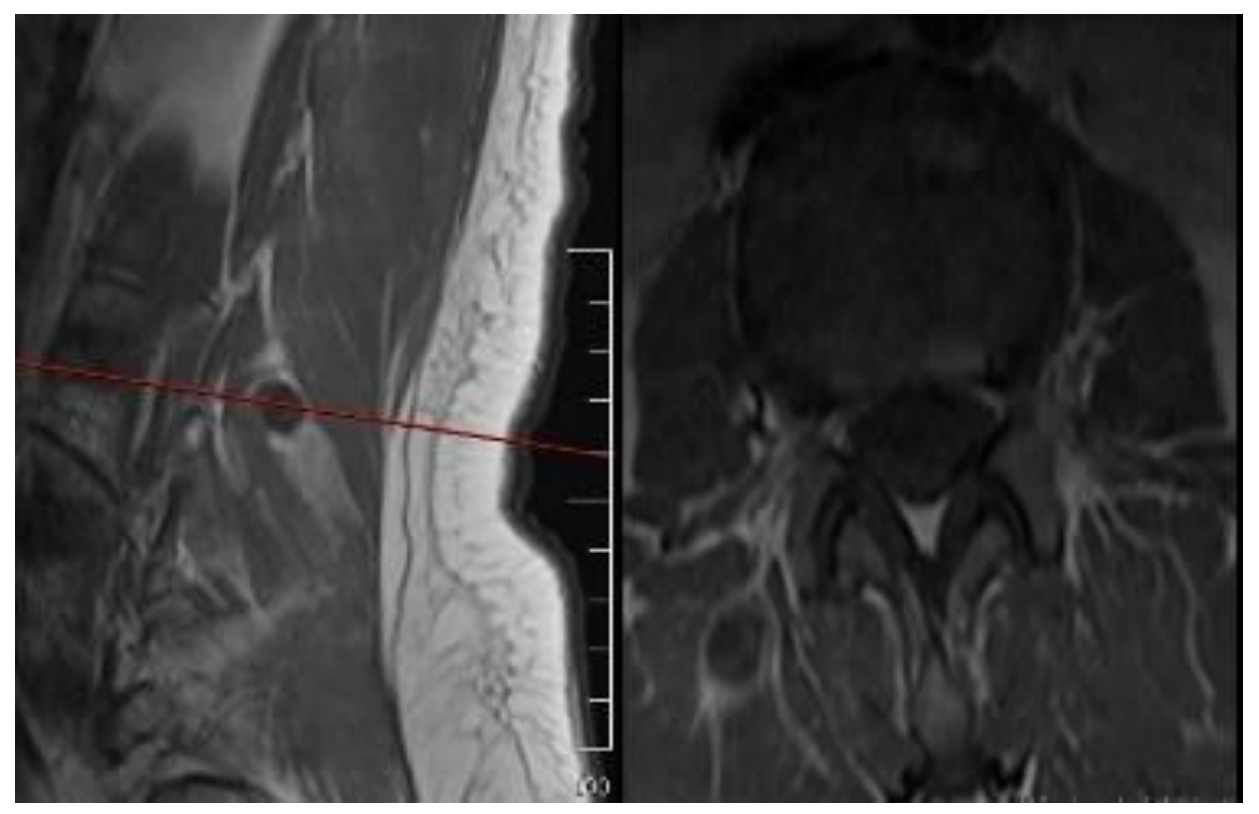

Figure 2: T1-weighted sagittal and axial magnetic resonance images. 


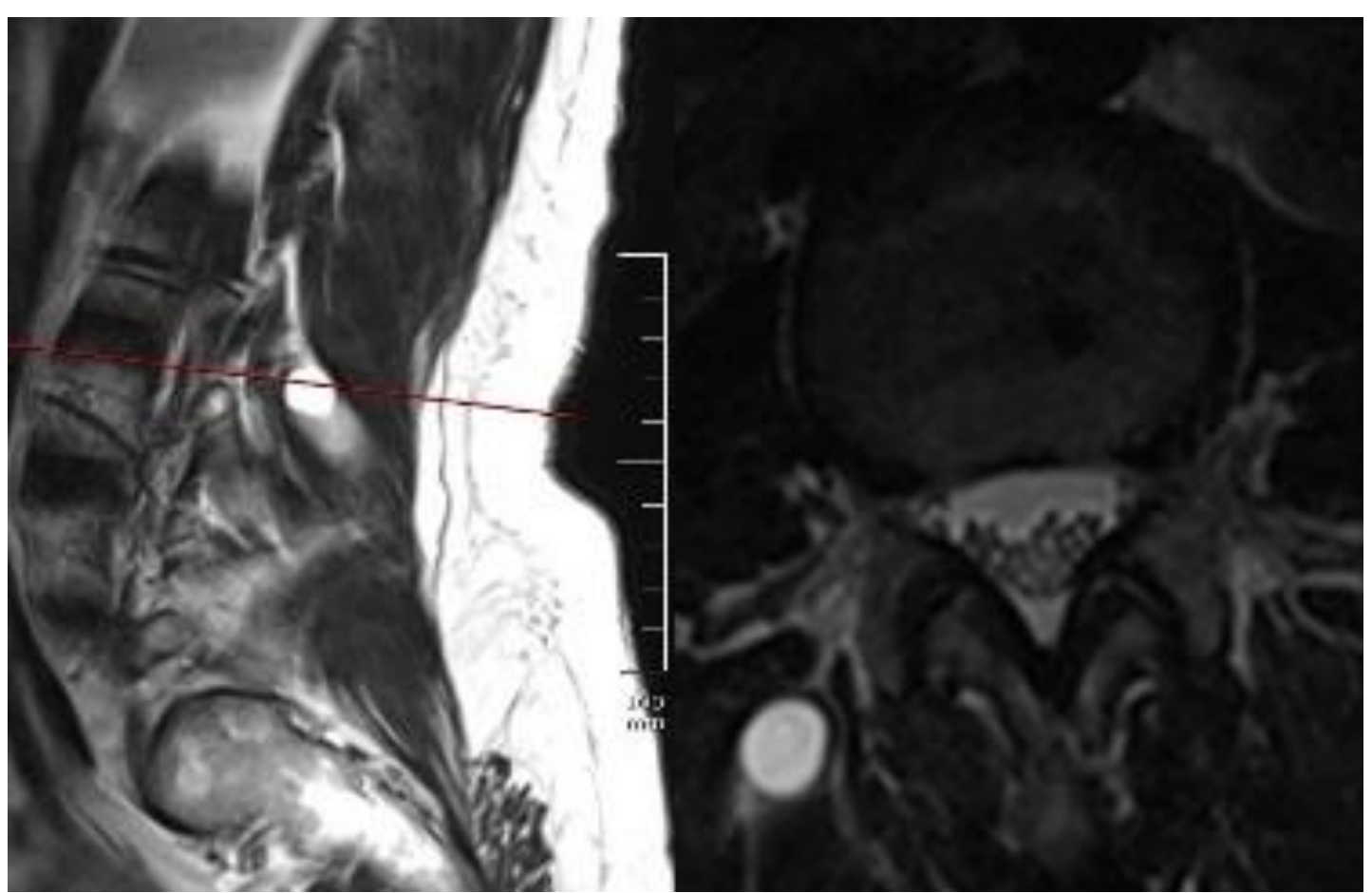

Figure 3: T2-weighted sagittal and axial magnetic resonance images.

We suspected paravertebral schwannoma. According to planned surgery patient went under surgery. Lesion found after right paravertebral muscle dissection. Lesion carefully dissected until the right L3-4 facet joint and totally removed adhering to microsurgery principles. We did not harm the root with a top-down approach.
Histopathological diagnosis confirmed

as schwannoma.

The patient followed for 2 years without pain and neurologic deficiency. Follow up magnetic resonance scan showed no residue or recurrence of the mass (Figure 4).

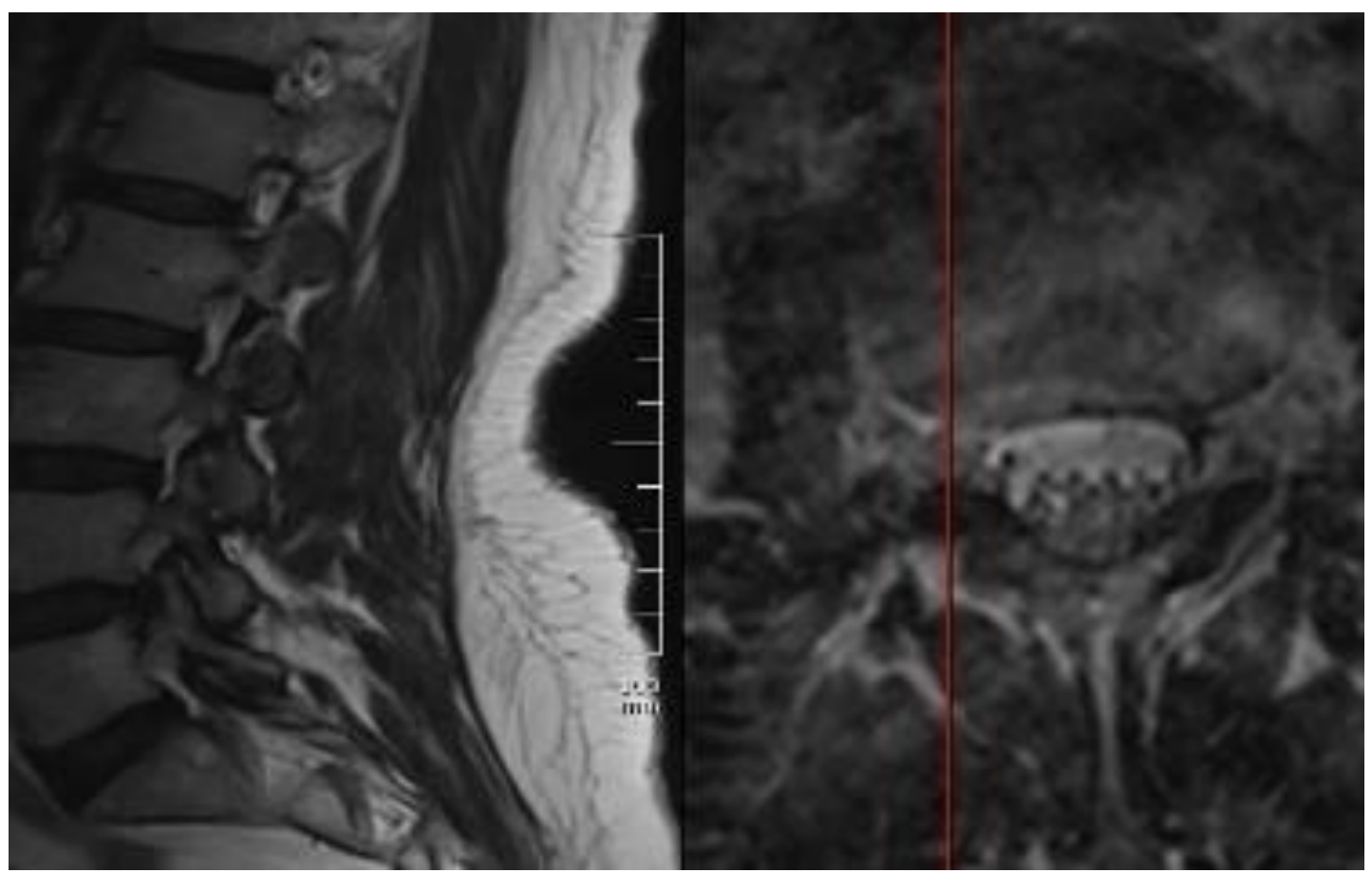

Figure 4: Follow up T2-weighted sagittal and axial magnetic resonance images. 


\section{DISCUSSION}

This case highlights one of the rare spinal causes of low back pain. Schwannomas are the most common peripheral nerve sheath tumors. ${ }^{1}$ It's originated from the Schwann cells. Schwannomas are also called neurilemmomas, usually seen between 30 and 60 years of age. ${ }^{1}$

Radiologically although neurofibromas and schwannomas can look identical, schwannomas are frequently associated with hemorrhage, intrinsic vascular changes (thrombosis, sinusoidal dilatation), cyst formation, and fatty degeneration. These findings are rare in neurofibromas. Signal characteristics at $\mathrm{T} 1$ weighted images $75 \%$ are isointense, $25 \%$ are hypointense; T2 weighted images more than $95 \%$ are hyperintense, often with mixed-signal; T1 weighted contrast-enhanced images virtually $100 \%$ enhances. $^{2}$ Due to the structure of the cases that cannot be classified precisely and their similarity to surrounding tissues, magnetic resonance images should be examined carefully. ${ }^{2}$ In the present case, although the patient applied to other clinics for a long time, she was undiagnosed due to lack of imaging compatible with the herniated disc clinic. In our case, the lesion was noticed in the axial images. We have found magnetic resonance imaging findings sufficient to explain complaints, as it is compatible with the examination. Therefore, no further investigation was requested.

Surgery provides good results with a very low rate of recurrence. Although the surgical method we used was known for muscle spasm after surgery, thanks to the microsurgical methods we used and the blunt dissection of the muscles, only the muscle spasm remained at the end of the first month and the patient recovered completely after the 6th month. Even though malignant transformation has been described before it's very rare. ${ }^{1,} 3$ Postoperative neurological deficits are rare (less than 15\%) it can last for months. A neurological deficit can be caused by the contusion of the remaining continuous nerve fibers. ${ }^{4-6}$

There are proposed classification systems but none of them covers all of the types. ${ }^{7,8}$ Our case presents one of the unclassified paravertebral schwannoma cases.

\section{CONCLUSION}

Schwannomas must take account for differential diagnosis of unexplained non-discogenic low back pain. New classification systems must be offered based on widespread patient groups.

\section{Acknowledgements}

Special thanks for my bellowed wife Damla KAYA unquestionable support.

\section{Conflict of interest}

The author doesn't have any potential conflicts of interest. This research did not receive any specific grant from funding agencies in the public, commercial, or not-for-profit sectors. This paper has been summarized as an electronic poster at the 31st Scientific Congress of the Turkish Neurosurgical Society.

\section{REFERENCES}

1. Khoshyomn, S., et al., Torsion of a lumbar nerve root schwannoma. Pediatr Neurosurg. 37(4): p. 206-9, 2002.

2. Beaman, F.D., M.J. Kransdorf, and D.M. Menke, Schwannoma: radiologic-pathologic correlation. Radiographics. 24(5): p. 1477-81, 2004.

3. Lahat, E., A.S. Rothman, and A.M. Aron, Schwannoma presenting as lumbar disc disease in an adolescent boy. Ann Neurol. 20(5): p. 6434, 1986.

4. Lu, D.C., S.S. Dhall, and P.V. Mummaneni, Mini-open removal of extradural foraminal tumors of the lumbar spine. J Neurosurg Spine. 10(1): p. 46-50, 2009.

5. Russell, S.M., Preserve the nerve: microsurgical resection of peripheral nerve sheath tumors. Neurosurgery. 61(3 Suppl): p. 113-7; discussion 117-8, 2007.

6. Rustagi, T., S. Badve, and A.N. Parekh, Sciatica from a foraminal lumbar root schwannoma: case report and review of literature. Case Rep Orthop. 2012: p. 142143, 2012.

7. Park, S.C., et al., Spinal intraosseous schwannoma : a case report and review. J Korean Neurosurg Soc. 46(4): p. 403-8, 2009.

8. Sridhar, K., et al., Giant invasive spinal schwannomas: definition and surgical management. J Neurosurg. 94(2 Suppl): p. 210 5, 2001. 